Abstract: This article examines how an after school comics club made a space for children's literacy practices. Twenty-one eight to ten year olds took part in the ten week project. During that time the children made their own comic strips, and worked in groups to create their own self-initiated publications. These comics were sold at two comics fairs, which were collaboratively planned and organised. In this article the multimodal medium of comics and will be explored. The concept of children's literacy worlds will be discussed in relation to identity. Text World Theory will be examined as a framework for analysing children's literacy worlds, with a particular focus on the bi-directional relationship between the discourse world and the text world. Action Research as a methodology is considered. Text World Theory is then used to interrogate the literacy worlds of two groups of children, examining the interplay of the discourse world and the text world of the two comics created. The article argues that the space for children to create their own, self-initiated narratives plays an important role in children's meaning making and exploration of identity, through a bi-directional relationship between their discourse and text worlds. Finally, the article offers suggestions for future practice.

\title{
Caticorns and Derp Warz: Exploring children's literacy worlds through the production of comics
}

\author{
Helen Jones
}

\section{Introduction}

"Build. Build things. Build friendships. Build yourself. Bit by bit. It may not feel like you are adding that much... but in the end, it will add up to a lot."

\section{- Awkward, Chamakova, 2015}

In her middle-school located graphic novel, Chamakova reflects on the antics of an afterschool art club who publish comic strips in the school newspaper. The significance is clear it is in the process of building, making and creating that we develop our sense of who we are, both socially and culturally, in relation to our identities.

In recent years, due to the constraints and pressures of an educational climate bound by a prescriptive curriculum and standardised testing, children's own interests and home literacy 
practices can become side lined within primary schools. Subjects such as art, design and technology, which develop an understanding of multimodality and the design process are increasingly marginalised (Ogier and Eaude, 2019). Meanwhile, reading is tested against a set of right and wrong responses. Recent research has shown that within schools, children view writing as a set of learned skills, which are compliant with specific tasks and procedures (Lambirth, 2016). This approach- whereby children are encouraged to read and write in order to tick boxes - fails to allow children to develop their own identities as readers and writers.

This article focuses on one strand of an action research project based at an after school comics club for Year 5 pupils (9 and 10 year olds), which examines how children explore identities and their worlds through the production of comics. Theories of multiliteracies will be discussed, alongside the concept of children's literacy worlds. Text World Theory will be considered and examined as a framework for analysing children's literacy worlds. Text World Theory is then used to interrogate the literacy worlds of two groups of children, and their comics, Caticorns and Derp Warz.

\section{Creating literacy worlds: multiliteracies, identity and cognition}

Developed as a concept by the New London Group (NLG), multiliteracies refers to the diversity of communication channels and media, and the increase of cultural and linguistic diversity in the modern world (Cope and Kalantzis, 2000). Through this lens, literacy is viewed as a social and cultural practice, which should be studied beyond the cognitive processes of reading and writing (Gee, 2015). While this distinction has led to some opposing understandings of what 'literacy' is, in recent years there has been an increasing willingness to view literacy as both a set of cognitive skills and social and cultural practice (Gee, 2014; Janks, 2010). In particular, there has been a recent turn towards the theory of the embodied mind which examines how the body is both a lived, experiential structure and the site of cognitive mechanisms (Varela et al., 1993). Pahl and Rowsell (2012) emphasise the materiality of literacy, arguing that it is a set of site-specific actions, which are handmade and artefactual. A current model of multiliteracies can therefore be seen to situate literacy in the connections between cognition, language, social and cultural domains and the materiality of the lived in world.

A key principle behind multiliteracies is the act of transformation (Kress, 2000), in which the resources used to communicate are the product of prior knowledge, based within the discourse world they inhabit. This process is often described as remixing, redesigning or reconstruction (Dyson, 1993; Kress, 2010; Janks, 2010; Pahl and Rowsell, 2012). 
The concept of domain - the particular space or world where literacy is practiced - plays a crucial role in the concept of multiliteracies (Pahl and Rowsell, 2012). Domains bring with them a specific set of discourse, the language used to signal membership to a specific speech community (Ibid.). Gee (2010) extends the concept of discourse to 'Discourse' with a big-D, the capitalisation indicating how we communicate beyond the verbal, including our style of clothing, and use of tools, symbols and objects. Within this framework, identities are directly linked to the discourse worlds we inhabit and cannot be separated from engagement in social practices (Comber and Mills, 2013). In a multiliterate world, the variety of domains and discourses each person might practice is multiple (NLG, 2000). Literacy therefore, cannot be considered something that only happens in a school environment, in the teaching of reading and writing, but something which people are engaging with at all times, in all contexts - as argued by Pahl and Rowsell, "by acknowledging your students' literary practices, you are acknowledging their identities" (2012, p.127).

Within education, the NLG argue for a pedagogical shift towards process, with a focus on the production rather than the reception of texts (Janks, 2010). In relation to the production of texts, writing, reading, seeing and listening are all considered instances of designing (NLG, 2000). From the field of cognitive psychology, a similar preposition is put forward by Oatley (2003, p.161), who argues that the word "writingandreading" should be part of the English lexicon. Concerned with the process that is occurring in the brain, Oatley argues that there is substantial evidence that as we perceive and understand the world through our senses, we are also constructing the world around us. In the act of 'writingandreading' we both assimilate to and project from the schema of what we already know to construct the world of the text. As a result the processes of reading and writing can be considered an inseparable process for making sense of the world.

\section{Children's literacy worlds}

By expanding the notion of literacy beyond the learning of reading and writing in school, a multiliteracies approach widens the field of study into children's home and personal interaction with texts. Much research has focused on the multimodality of children's home literacies, the role of community and the relationship to popular culture (Kress, 1997, Marsh and Millard, 2000; NLG, 2000; Pahl and Rowsell, 2012). Another area which has been greatly explored is how children's making of meaning in relation to texts and the world is situated within play as a collaborative process (Pahl and Burnett, 2013; Wohlwend, 2008; Wolf and Heath, 1992). Additionally, play has been examined as a form of identity performance (Dowdall, 2006; 
Wohlwend, 2008). Research has shown that through play, as children compose stories and imagine and reimagine the roles they take in the world, they critically engage their sense of identity linked to ideologies and popular culture (Dyson, 1997, Wohlwend, 2008). This engagement is hybrid, drawing from a range of cultural contexts (Pahl, 2006) and fluid between online and offline spaces (Mackey and Shane, 2013). Unlike school literacies, which are directed and supervised by the teacher, children's literacies outside of the school context are to a greater extent self-motivated, and led by their own interests. (Kress, 1997).

Stornaiuolo (2015), building on the work of the philosopher Goodman (1978), views children's literacy engagement as a world making process. Pulling together many of the stands of multiliteracies explored above, she defines this world making as:

"a process of constructing shared worlds through symbolic practice that intertwine the creative, ethical and intellectual in the art of making meaning from the multiple and dynamic cultural resources at hand" $(2015$, p.561)

This position is supported by Wilson (2016), who suggests that through creating comics children are experimenting with and remodelling personal world models. I find this a particularly useful concept, and have used the idea in what I have called 'children's literacy worlds'.

\section{Text World Theory}

Text World Theory, as defined by Gavins (2007) is a discourse framework, a means of analysing communication, concerned not only with how a text in constructed, but "how the contexts surrounding that text influences its production and reception" (p.8). In this respect it is an applicable framework in relation to the concept of children's literacy worlds, reflecting both social and culturally situated aspects of literacy, and the mental processes involved.

The theory is based on the work of Paul Werth, whose articles and manuscripts were brought together after his premature death and published together in 1999. Werth argues that humans conceptualise and make sense in discourse by constructing a mental representation in their mind, whether in the act of verbal communication or the process of reading and writing (Gavins, 2007; Werth, 1999). As a tool for analysis it has been mainly used within the field of cognitive poetics, particularly by Gavins (2007), who has developed and adapted Werth's original theories. 
Within Text World Theory, both readers and writers are seen as participants, co-constructing the act of communication. By positioning the reader as an active participant, Text World Theory develops and builds on transactional theories of reading (Iser, 1978; Rosenblatt, 1938). Communication is viewed as taking place in the "blanks and gaps" (Iser; 2006, p.64) that are negotiated in the process of reading and writing. This concept has also been explored within comics studies, particularly in McCloud's (1994) concept of closure. While explorations of multimodality through Text World Theory have been until recently quite tentative, there has begun to be interest in using this framework to analyse multimodal texts and most recently, comics and children's response to multimodal texts (Davies, 2018; Gibbons, 2012, 2016; Jackson, 2019; Taylor, 2018).

Text World Theory constructs a layered approach to examining different conceptual elements of discourse. Primarily, there is the discourse world - the immediate situation that surrounds two or more participants as they communicate (Gavin, 2007; Werth, 1999). For sense to be made in the discourse world, common ground has to be shared, and the less common ground there is, the more alienated one or more participants might feel (Ibid.). Into a discourse world participants may bring a range of knowledge, memories, hopes, beliefs, intentions, imagination, dreams (Werth, 1995, cited in van der Bom, 2015), the contextual factors that have the potential to impact upon "both the construction and comprehension of a given discourse" (Gavins, 2007). If participants in a discourse are not physically situated in the same space, for example in the case of a published book, then the communication is described as happening in a split-discourse world (Ibid.)

The second level of Text World Theory is focused on what is called the text world - the mental representations of the discourse world (Gavins, 2007). These are constructed through the world building elements of time, location, objects and enactors - the latter being 'characters', either real or fictional who inhabit the text world (lbid). Narratives are propelled forwards through function advancing elements, which communicate what is happening and how - in written language these might be prepositions or adverbs (Cushing, 2018). In the case of multimodal texts, such as comics, the world building elements are also visual, and the function advancing elements provided not just by the written words, but by transitions from panel to panel across the layout. For example, using McCloud's (1994) theory of panel-to-panel transitions in comics, both moment-to-moment and action-to-action transitions are examples of function advancing elements, in which the narrative is moved forward within the same text world. 
The relationship between the text world and the discourse world can be considered as bidirectional, acting also as a feedback loop (Canning, 2017; Lahey, 2019; Stockwell, 2009). As Canning argues,

"by jointly negotiating and co-creating text worlds, readers of literary fiction can go some way to understand not only their literary work, but their own and others views and experiences" (2017, p.185).

For children, therefore, exploring the text world as readers and writers can help them to make sense of the discourse world they are inhabiting.

The final layer of text world theory, focuses on world shifts, or switches, where the language communicates a shift, be it of place and time (deictic), of desire, belief and purpose (attitudinal) or of possibility and probability (epistemic) (Gavins, 2007; Stockwell, 2002). In comics studies, this aligns with McCloud's (1994) theory of subject-to-subject, scene-toscene, aspect-to aspect and non-sequitur transitions, which involve opened ended interpretations in which the act of closure is more complex and the reader has to fill the gaps. However, comics are not only read sequentially, panel-to-panel, but, as described by Nodleman, are "a pulsing and ever shifting movement in to and out of numerous possibilities of illustrative connections" (2012, p.439). Davies notes that hypotaxis (the grammatical concept of subordination) is central to comics design, having the "essential function of...creating spaces within spaces, and stories within stories, and logical relationships between images and text groupings that are not only a matter of juxtaposition in linear sequence" (2018, p.4-5). Linking this to Text World Theory, Davies calls this 'nesting', the way in which elements of world building and world shifts can occur simultaneously in the comics medium. For children as readers and writers of comics, these world shifts can be considered crucial elements of the design process, and the choices they make in the process regarded as part of their critical engagement with the text and discourse world. To use Text World Theory to examine children's literacy worlds, a model of analysis is proposed below, linking concepts from Text World Theory and comics studies (Figure 1). 


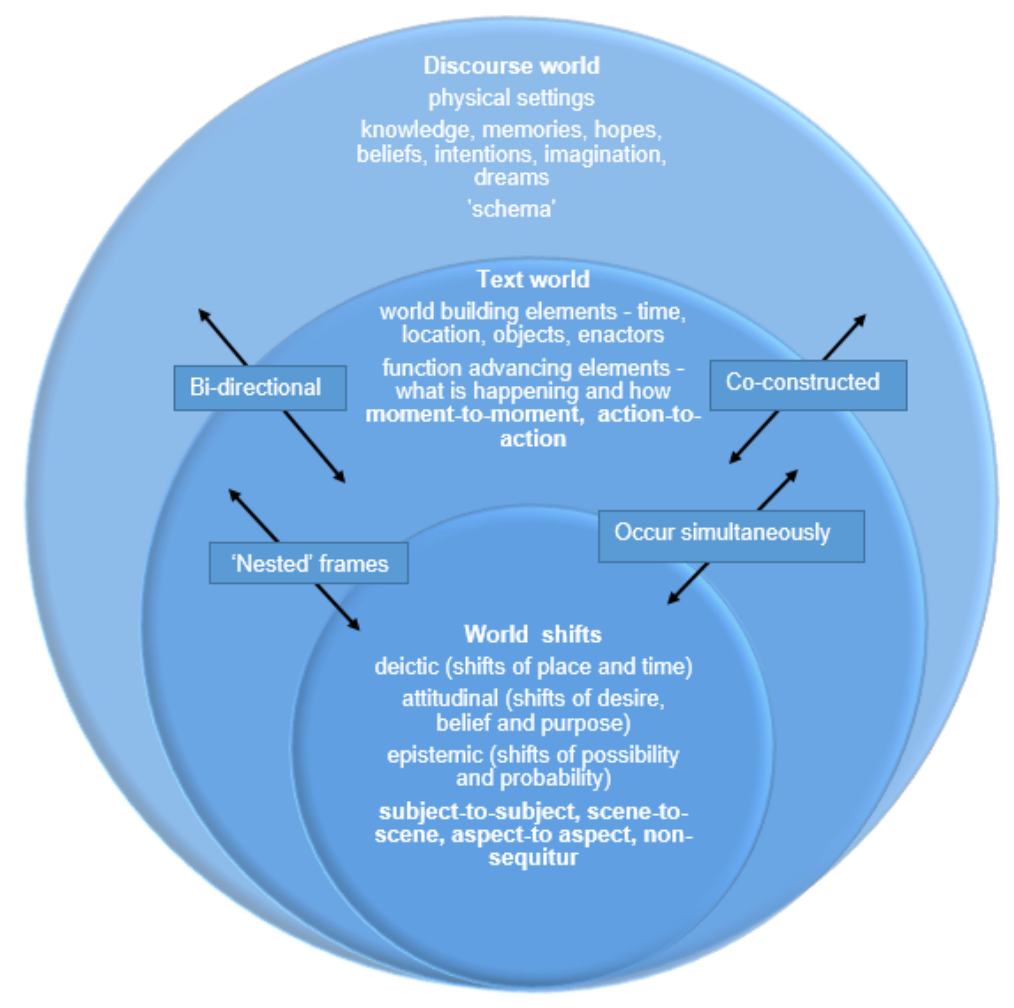

Figure 1: Text World Theory model of analysis

\section{Context}

The research took place in a primary school in South London. The school was known to me as the researcher as the school my children attend. The club ran one afternoon per week for ten weeks, in an after school time slot. Twenty children attended, with an average age of 10 years old.

Each child was given a sketchbook to use. The children took the sketchbooks home after each session in order to work on their comics and ideas during the week. A box of comics making tools were available during the meetings, including soft and hard pencils, a range of different fine line ink pens, colouring pencils and felt tips, sharpeners, rulers and soft rubbers. Each week the club started with a short activity on a specific skill the children had shown interest in, for example how to draw speech bubbles. The rest of the time pupils worked on their own ideas or their collaborative comics. Children also had access to a range of comics books and graphic novels, as well as 'how-to' books about comics making, all of which they could borrow to take home. 
Over the course of the project the children published several comic strips. The publications explored in this article were made by the children in small groups, working collaboratively to create comics to sell at two comics fairs, which were held in the school playground at the end of the school day. In these groups the children chose a name and created individual identities for their comics.

\section{Methodology and data collection}

In Action Research (AR) the researcher is embedded within the research itself, in selfreflection or collaboration with others, in a cyclical process of development (Bradbury, 2015; Carr \& Kemmis, 1986; McNiff \& Whitehead, 2010). The framework for AR enquiry is based upon a spiral of activity, which includes planning the research, acting this out, observing outcomes and reflecting on outcomes (Cohen et al., 2018). To collect data, a range of approaches were used. Following the methodology of AR, a reflective diary and field notes were maintained across the project. In addition, semi-structured interviews were held with groups of children. Photographs were used to record observations and events. Data was also collected through children's sketchbooks and the comics that were produced through the course of the project. Parental and children's permission was agreed and data was collected under voluntary informed and ongoing consent. In the presentation of data, all names have been changed to preserve anonymity.

\section{How do children explore identities and make meaning through the production of comics?}

To investigate the relationship between children's text worlds and discourse worlds, Text World Theory is applied to two of the children's comics - Caticorns and Derp Warz. The framework (shown in figure 1 ) is used to examine how children make literacy worlds in which they collaboratively play with multiple identities. It is also used to consider how children critically redesign the discourse worlds which they inhabit. Of particular importance to the question of how children explore identity and make meaning is a focus on the bi-directional relationship between the discourse and text world, and how elements of the text world are used critically as choices in the design process. 


\section{Caticorns}

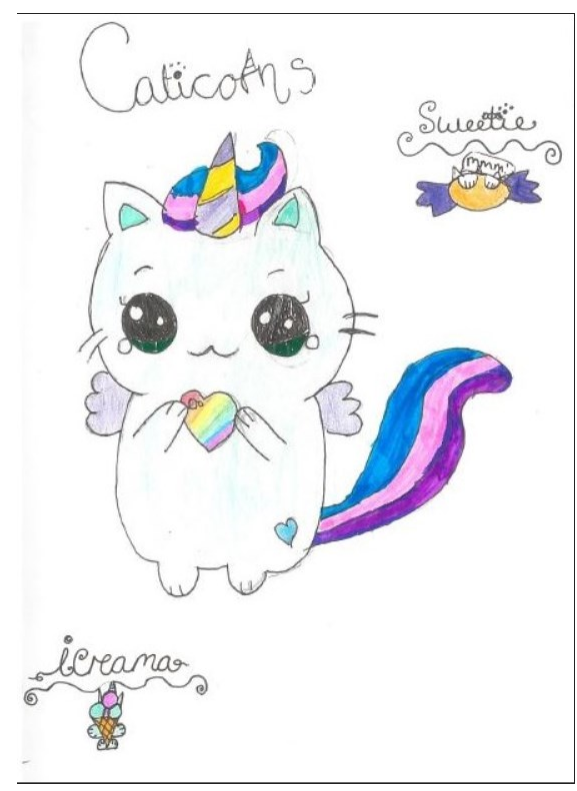

Figure 2: Front cover of Caticorns comics

Caticorns (Figure 2) was created by four girls, Summer, Katie, Vanessa (all ten years old) and Loulou (aged eight). Two of the children were my own daughters, affording me much common ground and insight into their discourse world (Werth, 1999). Across the two comics fairs, this comics was the most popular, selling out its print run of 40 copies.

\section{The discourse world of the Caticorns}

The elements of the Caticorn's discourse world were multimodal, and used to signal their interests and identities (Gee, 2010). When interviewed about the inspiration for the comics, the group discussed the following:

Summer: Well, ummm, we wanted to do a comics about unicorns and cats, so we just mashed it together and decided we would do one about caticorns.

Katie: Yeah.

Me: $\quad$ Yeah? And where did you get the ideas for the pictures from?

Summer: $\quad U m m . .$. 
Me:

The way you drew it?

Vanessa: Cos we had, cos we wanted to do, like, sweets, so we kind of made our caticorns like a sweet or a candyfloss or like, whatever...

Me: $\quad$ Ok, good ...and were there like any pictures that you saw, or any films you like, that you think are similar to it?

Summer: Well um, well me and Katie like looking at kawaii pictures, so we got our inspiration from that...

Me: $\quad$ What are kawaii pictures?

Summer: $\quad$ Like really cute pictures

Katie: $\quad$ Kawaii means...

Summer: $\quad$ Cute in Japanese!

These influences were found in the children's clothing, for example two of the girls wore cat ear headbands to school, and one wore a Manga cat badge (Figure 3).

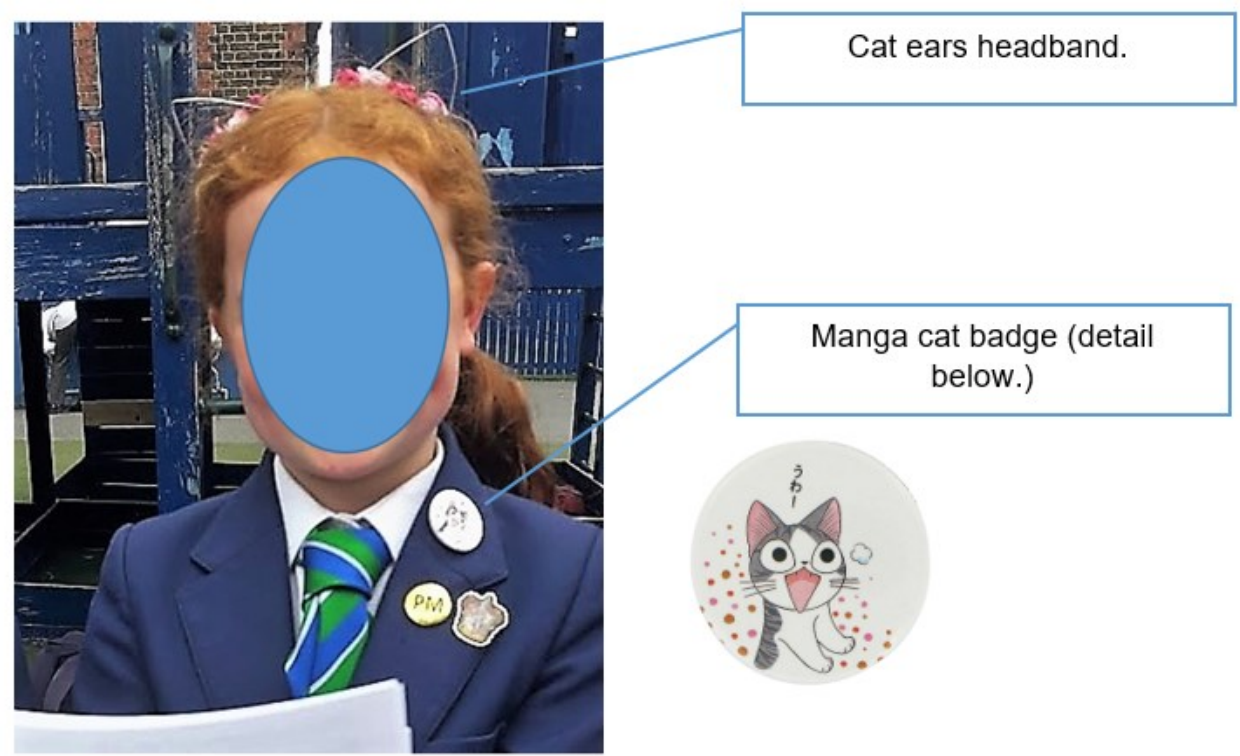

Figure 3: Cat and Manga items of clothing. 
My daughter Summer's desk at home contains many artefacts, both part of her play and making, which reflect the elements of the discourse world discussed, and reflect a range of popular culture (Figure 4):

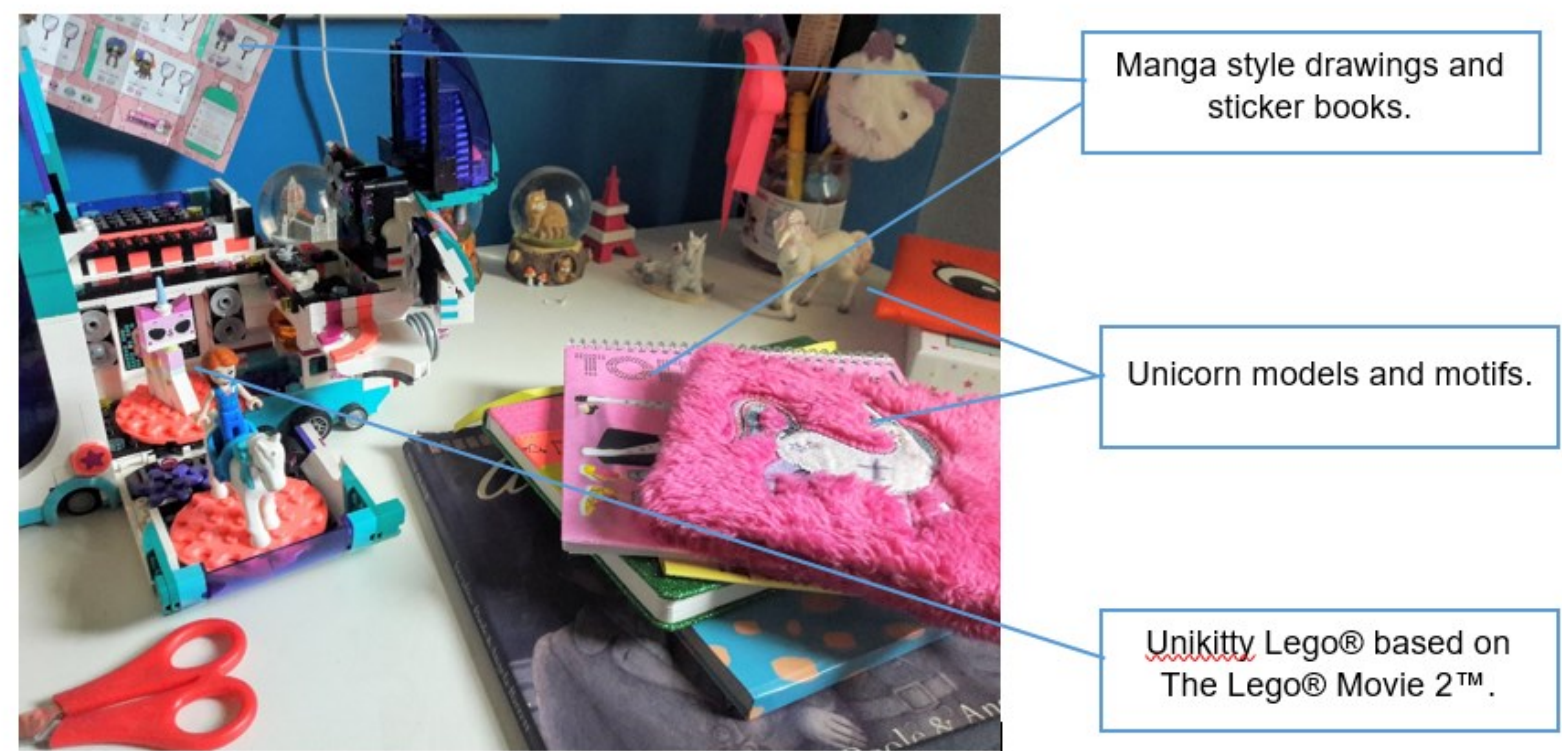

Figure 4: Summer's desk.

A strong affinity across the group was an interest in the Manga style of kawaii (cute), identifiable from its large, expressive eyes and small mouths, often large heads and smaller bodies (Brophy, 2010). This style has become popular across the world, in cartoons and commercial goods (Pellitteri, 2018). The children enjoyed copying this style of Manga in their sketchbooks (Figure 5): 


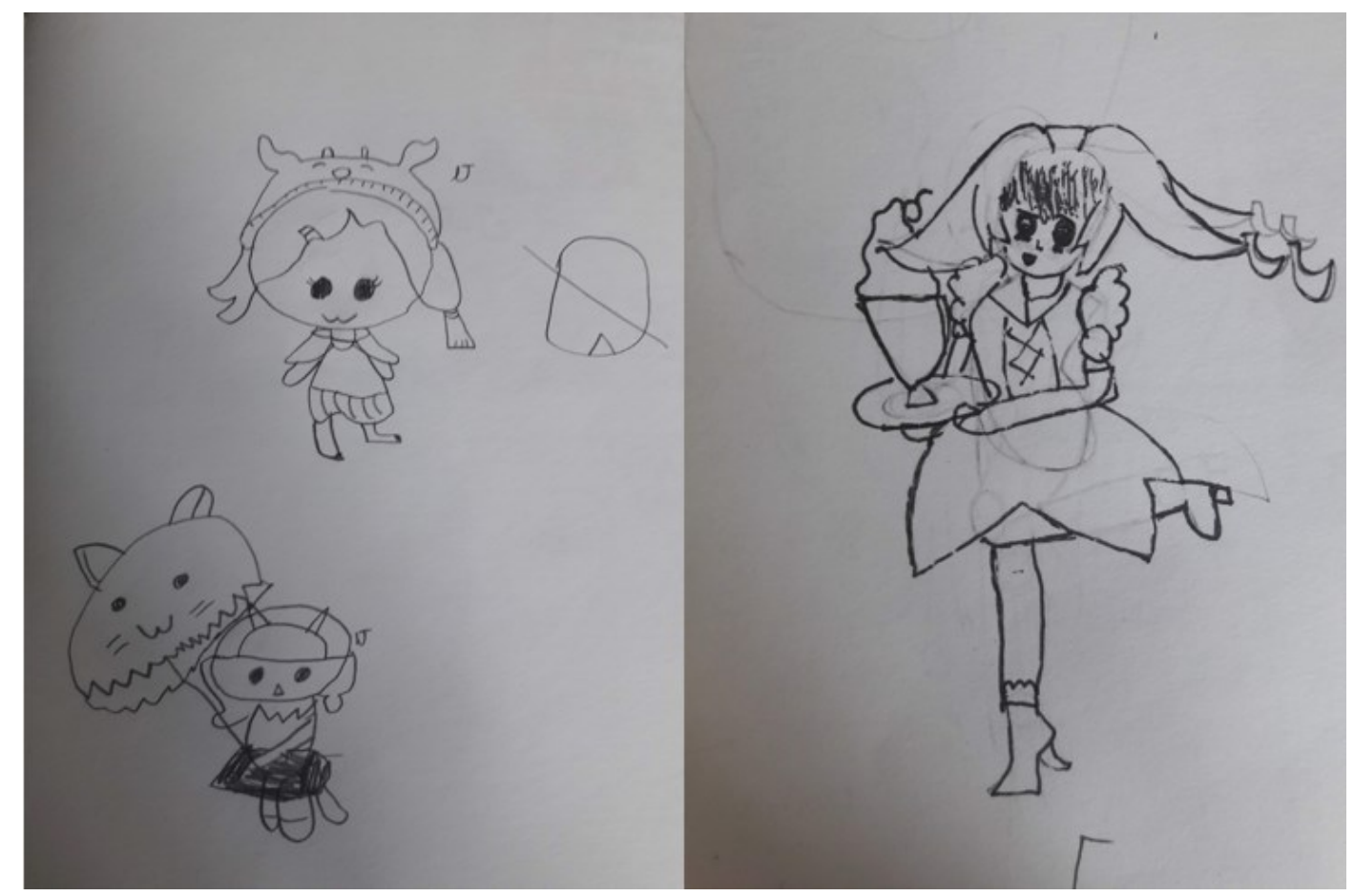

Figure 5: Manga drawings in Summer and Loulou's sketchbooks.

These elements of the discourse world helped to form the group's identity, through their affinity with kawaii, cats and unicorns (Gee, 2017). In the interview above, Summer mentions the idea of 'mashing together' these elements, a concept related to the idea of remixing and redesigning. Through this remixing of shared elements of their discourse world, the girls created their own group identity.

The shared discourse makes visible the children's relationship to contemporary global discourses and cultural practices (Wholwend et al., 2018). This may be a reason why this comics sold the most at the comics fair, as by utilising aspects of current popular culture the discourse world was familiar and accessible to the group's peers.

\section{The text world of the Caticorns}

Each child in the group created their own character, similar to creating an avatar, in order to explore their imaginary, collaborative world (Wholwend et al., 2018). These characters were all female, suggesting that the girls were using these character to play with typical female identities (Dyson, 1997). In this imaginary world the characters are often part of each other's storyline (Figure 6). The characters are all related by their names linked to sugary food items, and drawn in in a kawaii style. The jointly created text world is thematically and visually cohesive. 


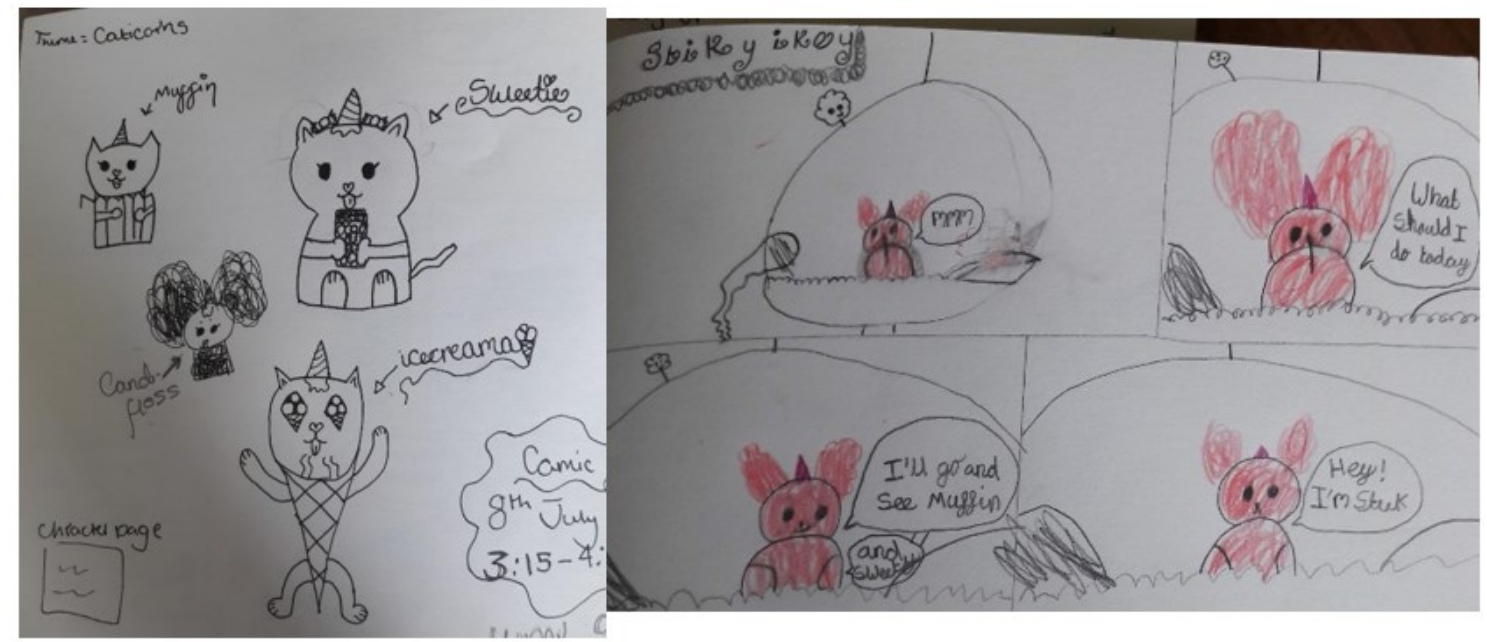

Figure 6: Caticorn characters and examples of storylines involving each other's characters.

'Caticorns go viral' is the name of the comic strip co-created by Katie (storyline) and Summer (drawings). In the comic strip, the characters of Muffin and Sweetie are involved in a storyline that includes videos 'going viral' (widely shared on social media) and maintaining friendships, highlighting the children's consideration of current global discourses (Wholwend et al., 2018). 


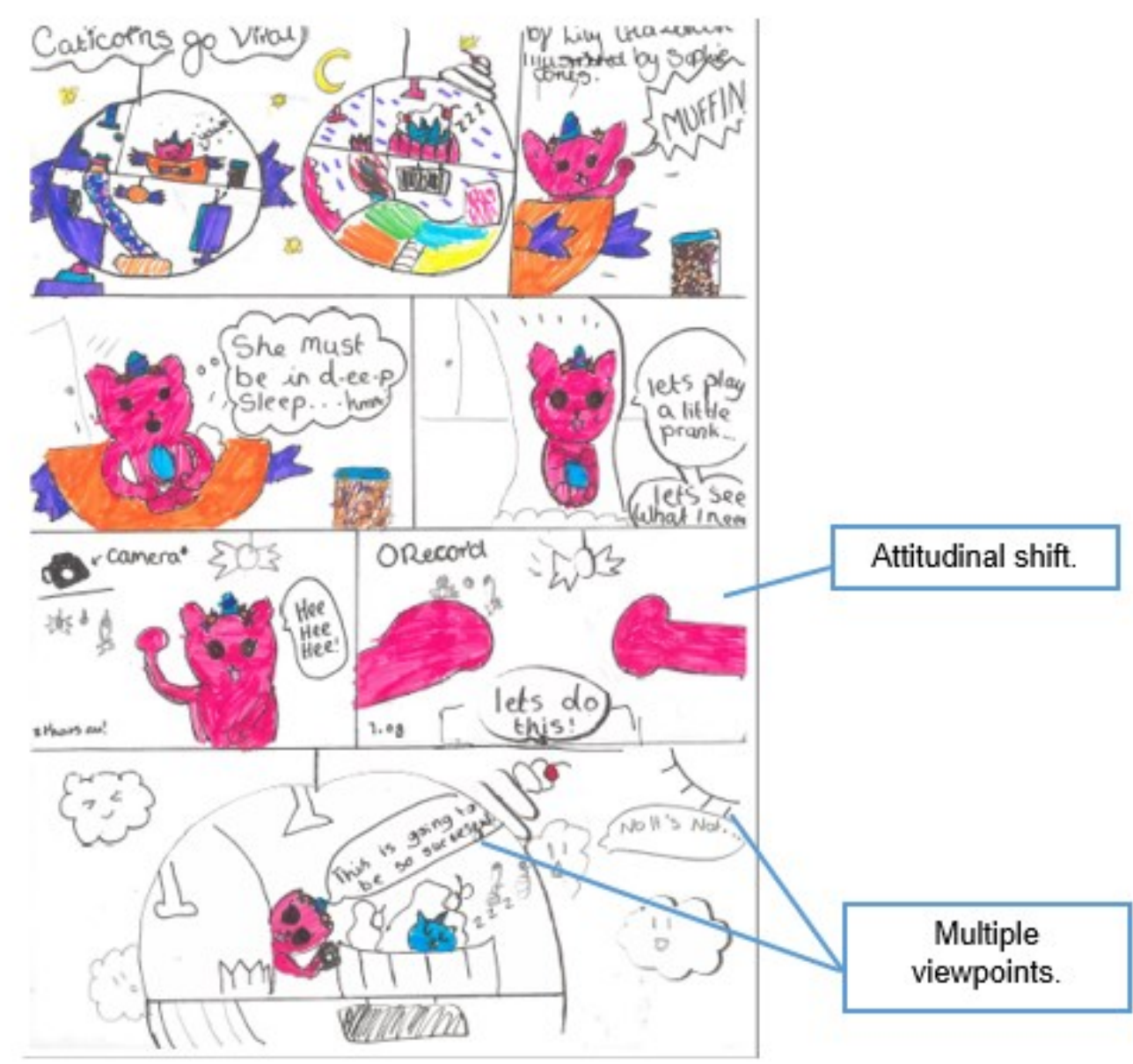

Figure 7: Page one, 'Caticorns go viral'.

World building elements of the text are multimodal (Figure 7). In the first panel time is shown through both the symbolic drawings of stars and the moon, and the written sound effects 'yawn' and 'zzz'. The location and objects in the physical landscape of the text world are drawn, but also identified by labelling. The enactors are presented both through the drawings, the title and the sounds that they are making. Across the page of the comics, framing is used to focalise attention to specific enactors, as is colour, each character having a specific colour, and the majority of the rest of the text world rendered in black and white. The majority of panel transitions are action-to-action, acting as function advancing elements for the narrative. Through the application of different modes to communicate world building elements, the two children show a complex understanding of the multimodal design process.

World shifts occur when transitions between panels become more complex. Between panel four and five (Figure 7), the transition switches to aspect-to-aspect, as the audience views 
the scene from the perspective of Sweetie looking through the camera. This attitudinal shift takes the audience from being neutral observers, to being the protagonist, pranking her friend by filming her while she is asleep, inviting the audience to share her viewpoint (Taylor, 2018). Different viewpoints are also demonstrated through the use of thought and speech bubbles. In panel six (Figure 7) Sweetie's speech bubble contrasts with the speech of a personified cloud, who acts in a narrator role, speaking directly to the audience. The direct narration to the audience by enactors in the text world can be considered as similar to breaking the fourth wall in film and theatre. It also occurs visually in panel three (Figure 8), when the shocked Muffin appeals directly to the audience.

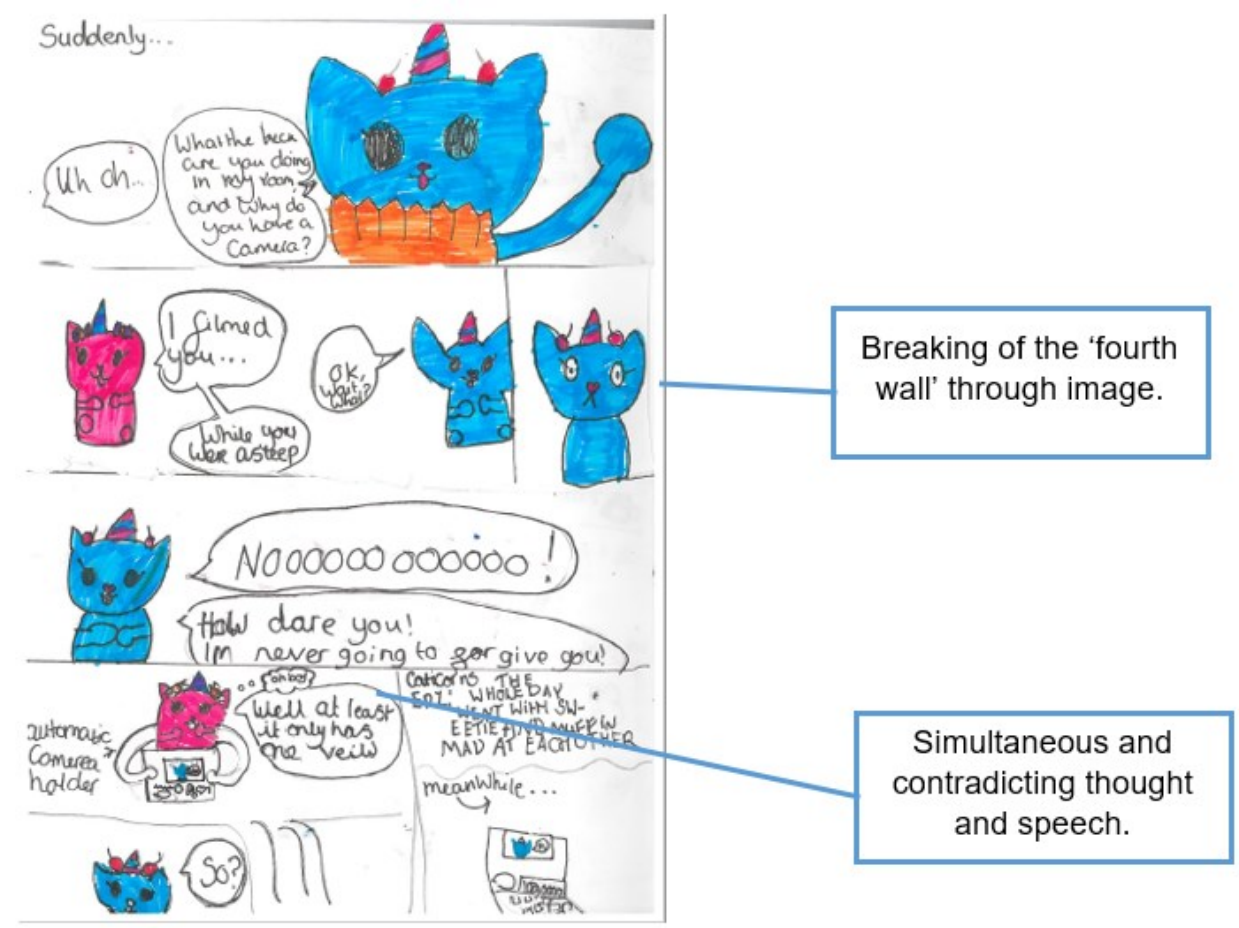

Figure 8: Page two, 'Caticorns go viral'.

In panel five (Figure 8) thought and speech bubbles are used to show the contradicting thoughts (oh boy!) and spoken words of Sweetie as she tries to calm down her friend. Through the switching of perspectives and attitudes, the two children demonstrate a metatextual awareness of how comics are organised and structured, a meta-linguistic understanding of how different modes can communicate in combination with one another and a meta-contextual awareness of how the comics they have created fits into the wider context of the world (Horning, 2011). This supports Tarbox's (2017) argument that comics can heighten the awareness of the 'constructedness' of the text world. 


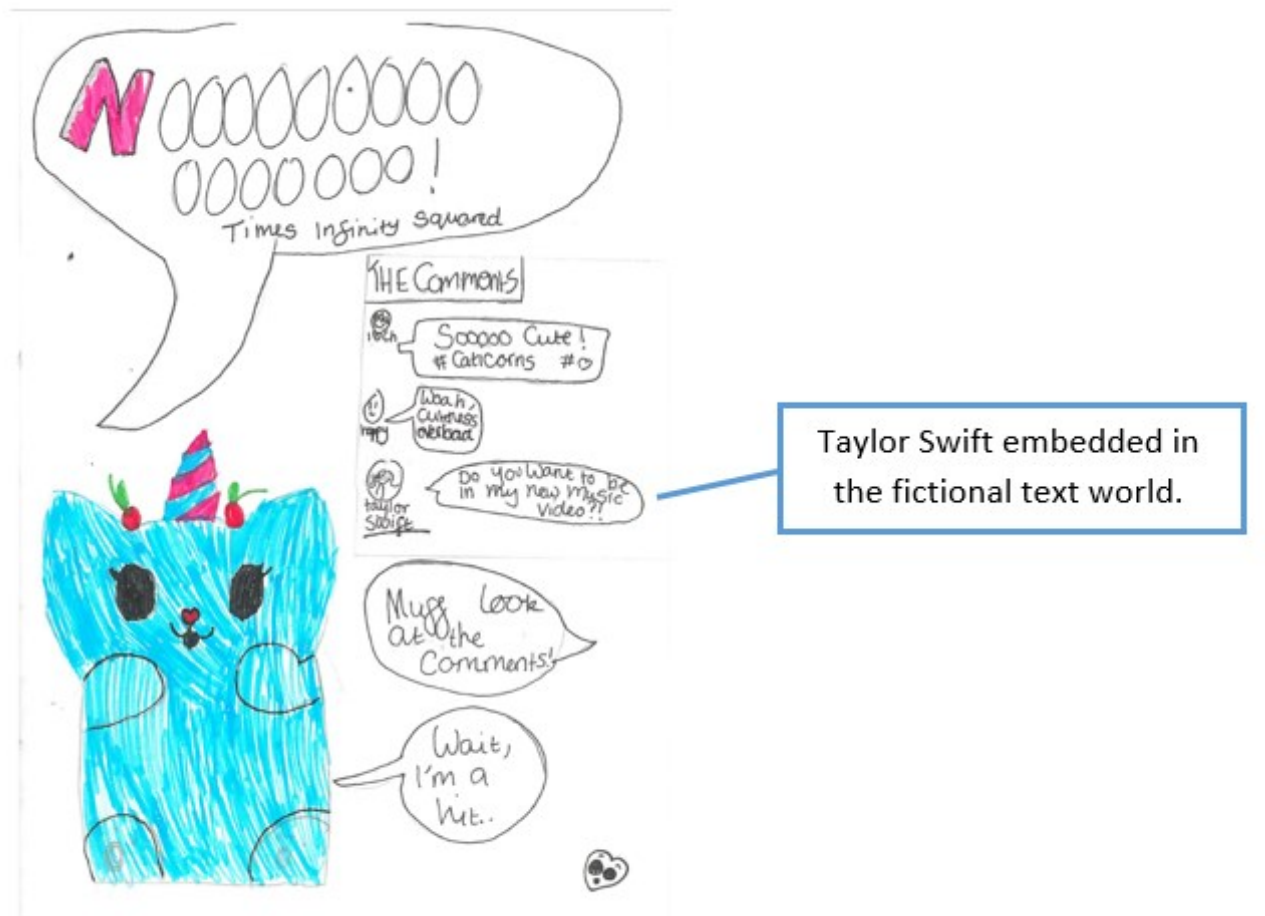

Figure 9: Page three, 'Caticorns go viral'.

In the page above (Figure 9), the lack of a frame around the image creates space, inviting the audience to enter the text world (Eisner, 1985). Within this is a nested frame (Davies, 2018), showing the comments thread of a social media site, featuring the real life pop star, Taylor Swift. Real life characters are embedded into the fictional text world of the Caticorns, demonstrating how the children are using the text world to explore their meaning making of the real world.

In creating the text world, children are make sense of their own views and experiences (Canning, 2017). In the design of 'Caticorn's go viral', Summer and Katie are making sense of their discourse worlds through playing with narratives in the text world. 'Going viral' is shown as being both good and bad. The text world has a bi-directional relationship with the discourse world and the comics engages with the audience about the text world (Taylor, 2018). Multiple attitudes towards friendship and social media are explored through playing with the multimodality of the medium. Concepts of identity are explored in relation to the children's discourse world, popular culture and the wider world. Crucially, through the comics club project, the group were able to explore what is important to them, related to the larger culture around them, and through the production and distribution of the comics, share this with others. 


\section{Derp Warz by Doodle Boiz}

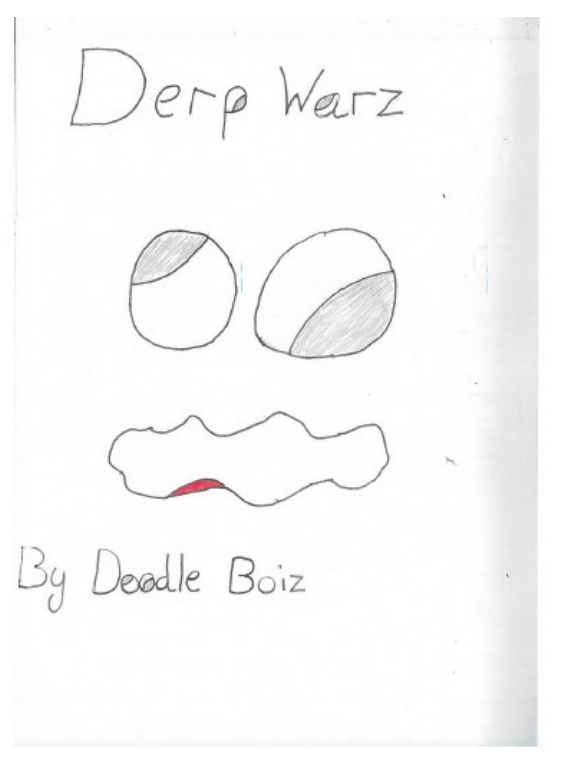

Figure 10: Front cover of Derp Warz by Doodle Boiz comics

The Doodle Boiz (Figure 10) were four boys, Isaac, Malik, Jacob and Jayden, all ten years old. They occasionally frustrated me and the teacher during club sessions, drawing when the rest of the club were having discussions, and then sitting back and chatting when they were asked to work on their comic strips. However, they were highly enthusiastic and attended every week, worked on their comics at home, and came and told me excitedly if they had done anything related to the club - for example, attending a MCM Comics Con.

\section{The discourse world of Derp Warz by the Doodle Boiz}

In the name they adopted for their comics, it was very important to the group that the plural was spelt with a ' $z$ ' rather than an 's', a spelling pattern associated with youth and urban culture, slang and rap music, as is the spelling of 'boi' instead of 'boy'. While this was familiar to me, when they told me the name of their comics, I was confused by the term 'derp' and asked them what it meant. Jayden was effusive - "they're the greatest memes ever - they are so stupid and funny!", and Malik told me that 'derp' meant "cuckoo crazy". In this discourse world, I shared much less common ground than I did with the Caticorns, and this lack of shared discourse meant that I was primarily disconnected from the world (Werth, 1999; Gavins, 2007).

My curiosity raised, I investigated. A meme is an image that is used to convey meaning and is spread by copying or imitation (Shifman, 2014). 'Derp' is an expression associated with 
stupidity, much like 'duh' and a derp meme is a character typically portrayed with eyes that are pointed to each side (Figure 11).

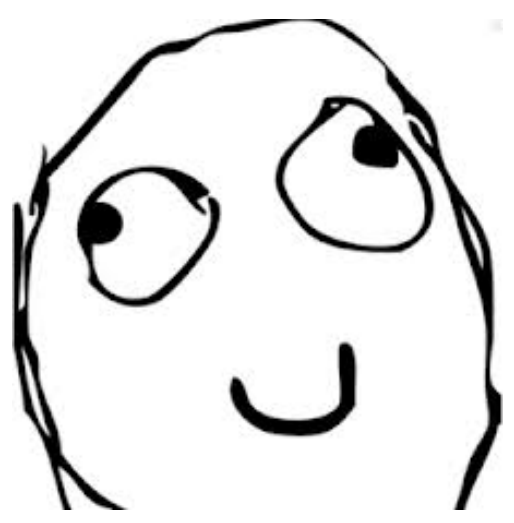

Figure 11: Derp meme (https://imgflip.com/memegenerator/Derp)

Derp memes are used to make 'rage comics'. These are web comics, found on social media sites such as Reddit. Characters are created with simple drawing software, or copied and pasted in new narratives. The style of drawing is intentionally badly rendered and often uses stick figure bodies.

From the names and image of the front cover of their comics (Figure 10) the Doodle Boiz identify themselves with the discourse world of rage comics. Both images and text reflect this, with the cross-eyed motif repeated inside the written text. Similar to Caticorns, social media infiltrated the discourse world of both the written and visual elements of the comics, and were used by the four boys to create their text worlds.

As well as derp memes and rage comics, the group reported that comics based films such as The Avengers inspired them. However, the boys were keen to point out that they did not directly copy:

Malik: $\quad$ I was just thinking about what I like, like mixing films and dreams, so, like, don't copyright characters but put your own twist on the characters.

Jacob: Well what I thought...I got, like, my ideas from pretty much my imagination, just come up with some weird characters and some weird names and umm, just to make the mood more happier and make sure I don't copy completely. If I like see a character that I like in a comics or like a tv show, I don't copy it, I magpie ideas, like appearance and how they act so then I make my own character. 
Similar to Caticorns is the idea of remixing ideas from a range of sources, demonstrating that both groups had an awareness of how they were using elements from a range of media to create their text worlds. In addition, both Malik and Jacob show an awareness of copyright, and ownership of ideas. For them it was important that the comic strips they created were seen as their own work, even when remixing or developing ideas based on popular culture (Figure 12). Kress (2010) argues that this idea of authorship is strongly linked to identity. For the Doodle Boiz, the right to exert copyright over their comic strips gave them ownership over the text worlds they were creating.
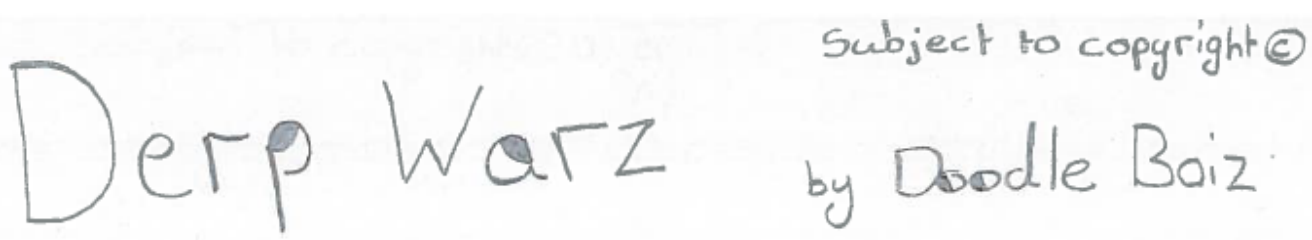

Figure 12: Copyright symbol.

\section{The text world of Derp Warz by the Doodle Boiz}

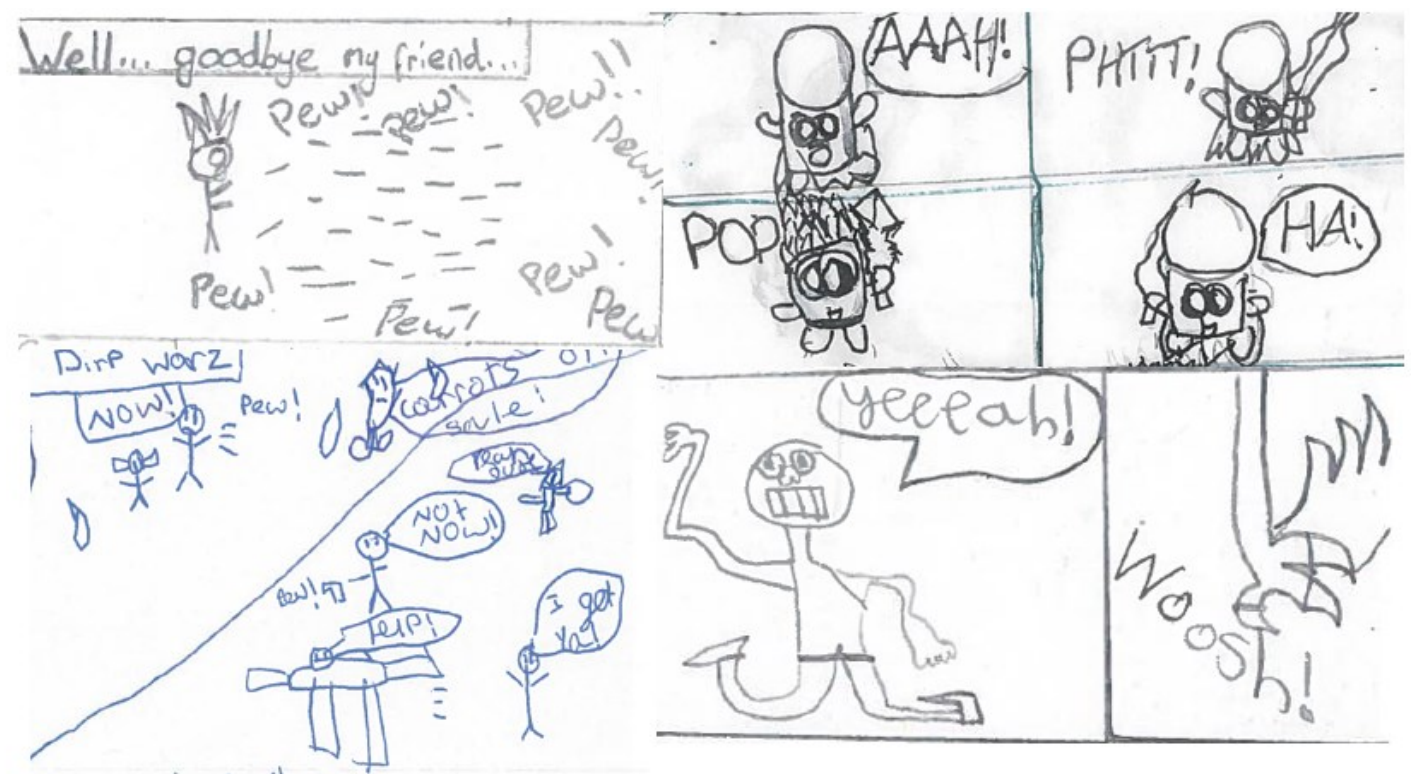

Figure 13: Examples of the four comic strips that were in the collaborative comics.

The Doodle Boiz creations (Figure 13) are in a similar style to each other, line drawn, with empty backgrounds and stick figures. They all used colour sparingly, usually only red to 
indicate blood (or ketchup, Figure 19), a style reflected in the front cover of the comics (Figure 10). As with the Caticorns, the Doodle Boiz created a coherent text world for their characters to inhabit. Each member of the group created their own comic strip, but they all had similar narratives, involving 'warz' between characters. These wars were not serious, and had random and surreal elements, for example, Malik's comics in Figure 13 depicts a carrot arriving to sell carrots in the middle of a gun battle, and being told "not now". As Jacob told me, this was important to the story telling, and referenced Marvel:

"they have some funny moments in Marvel, it's not just pure gory and all of that, sometimes they make the mood kind of happy, cos they like crack a joke or something."

As the name tells us, Derp Warz are stupid wars, not to be taken seriously. Although the narratives take place in an all-male world of conflict (Dyson, 1997), it is clear that these stories are funny and the Doodle Boiz may well be seen to be playing with cultural concepts of masculinity and identity.

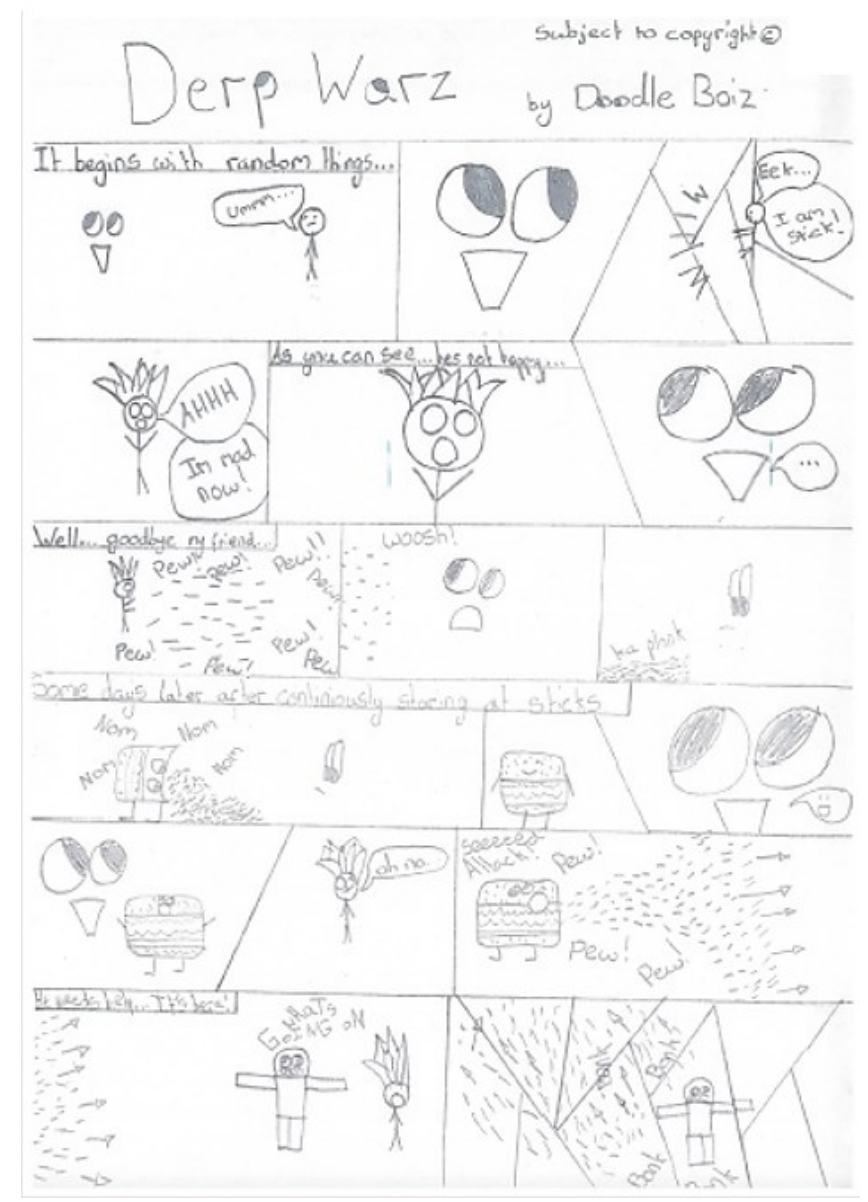

Figure 14: Page one, Jacob's comic strip. 
The world building elements of Jacob's comic strip are sparse (Figure 14), and create a world with different logical rules to our own, requiring the audience to use their imagination to fill the gaps (Gavins, 2007; McCloud, 1994). As with the Caticorns, world building elements are presented through the multiple modes. The enactors of this world are four surreal characters, $\bullet \bullet \bullet \bullet$, Stick, Derp Workz and Burger Boi (Figure 15).

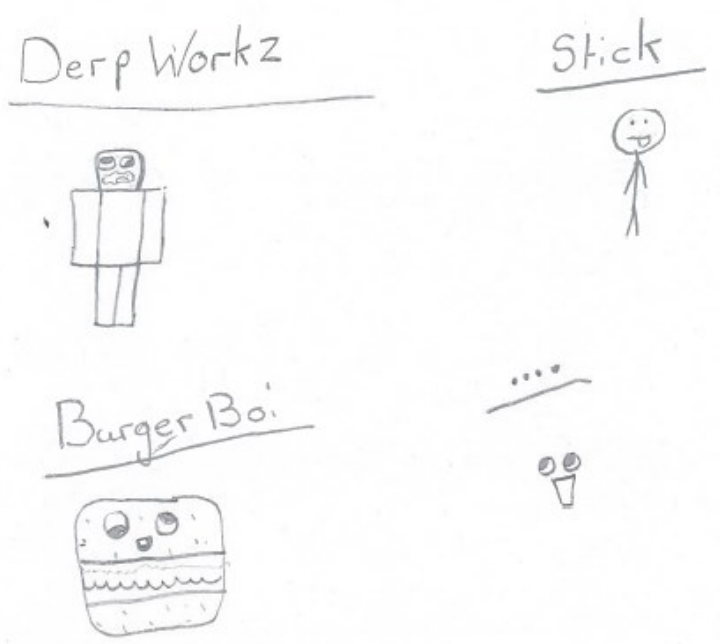

Figure 15: Jacob's characters.

Time is communicated through a caption "it begins" (Figure 14). Jacob use captions to narrate and create function advancing mechanisms, such as time and what is happening. Through juxtaposing the captions with the function advancing panel-to-panel transitions Jacob plays with humour. In Figure 16, for example, between panel A and panel B, the disembodied face

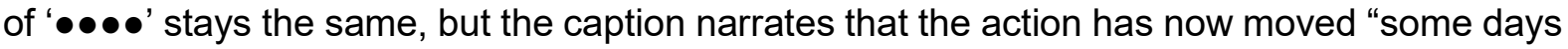
later after continuously staring at sticks". Jacob demonstrates the ability to play with juxtaposition to create comedy.

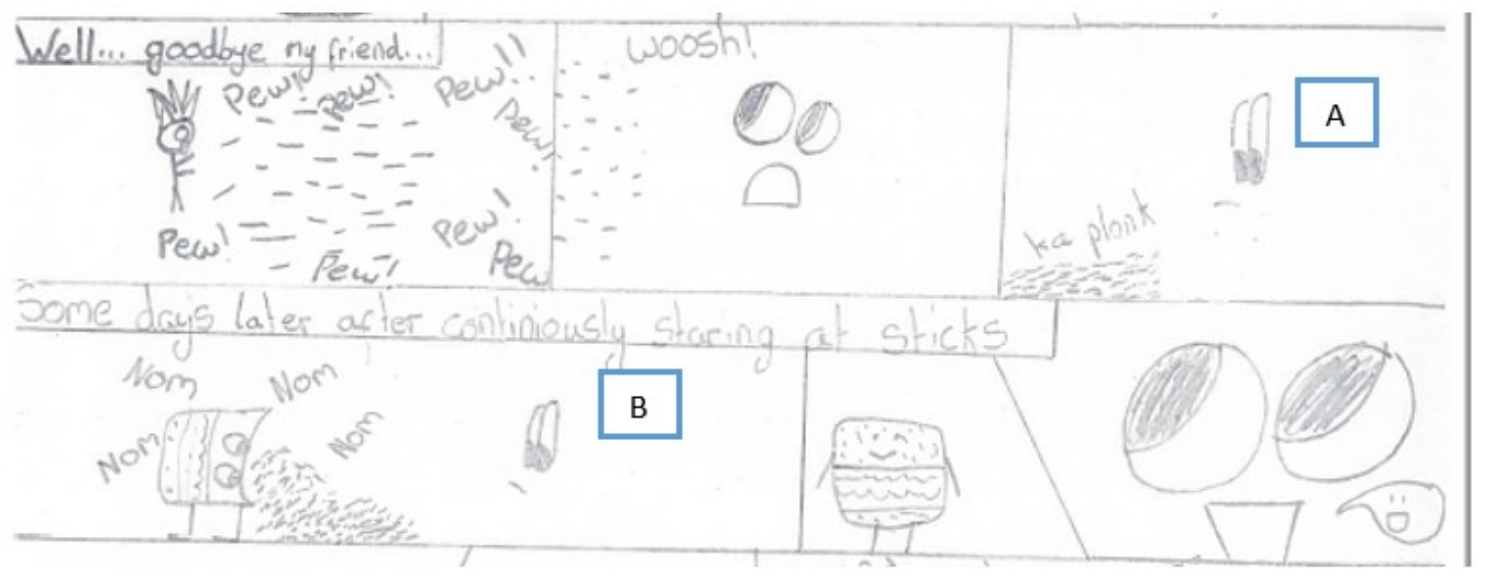




\section{Figure 16: Section of page one.}

Captions are also used to communicate directly with the audience (Figure 17) engaging with the reader directly about the text world (Taylor, 2018).

Figure 17: As you can see....

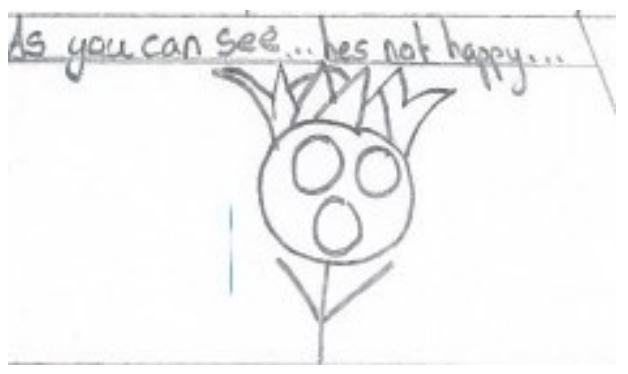

The location and the objects within the text world point to its constructed nature (Tarbox, 2017). The location is the white background of the paper, and the characters use the frames as objects by interacting with them (Figure 18).

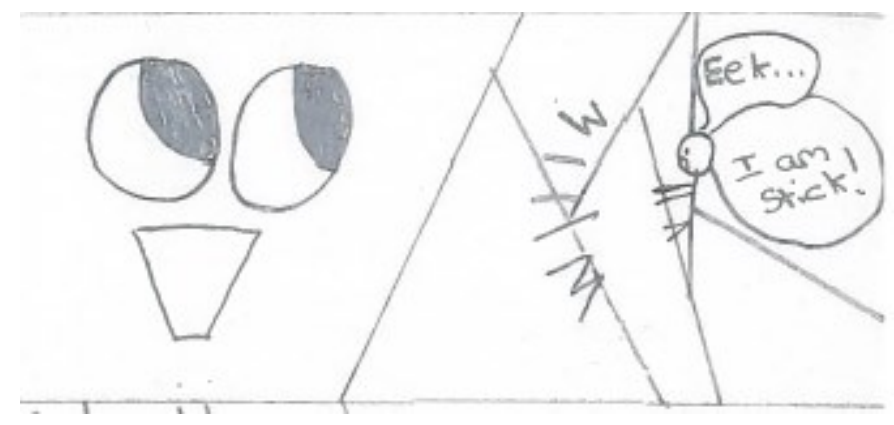

Figure 18: Eek...I am a stick!

Sound effects, for example 'nom', 'pew', 'woosh' and 'karplonk' are also function advancing elements of the narrative, telling us how objects are moving and what characters are doing (Figure 14). Speech bubbles include faces, communicating as emoji (ideograms). Through these design choices, Jacob blurs the line between image and written word as modes (Cohn, 2016; Kress and Van Leeuwen, 2001, McCloud, 1994). 
At the end of his comics (Figure 19), Jacob directly addresses the audience again - writing in the final two panels "NONE OF THIS HAPPENED, NONE OF IT", alongside two 'faces' staring out, breaking the fourth wall, again highlighting the constructed nature of the text world (Tarbox, 2017). Jacob demonstrates a meta-awareness that allows him to play with how the design process works, and use this to communicate his interests and ideas with his audience, engaging them in the process (Horning, 2011). Jacob's text world is deliberately silly, constructed, and a place to play.

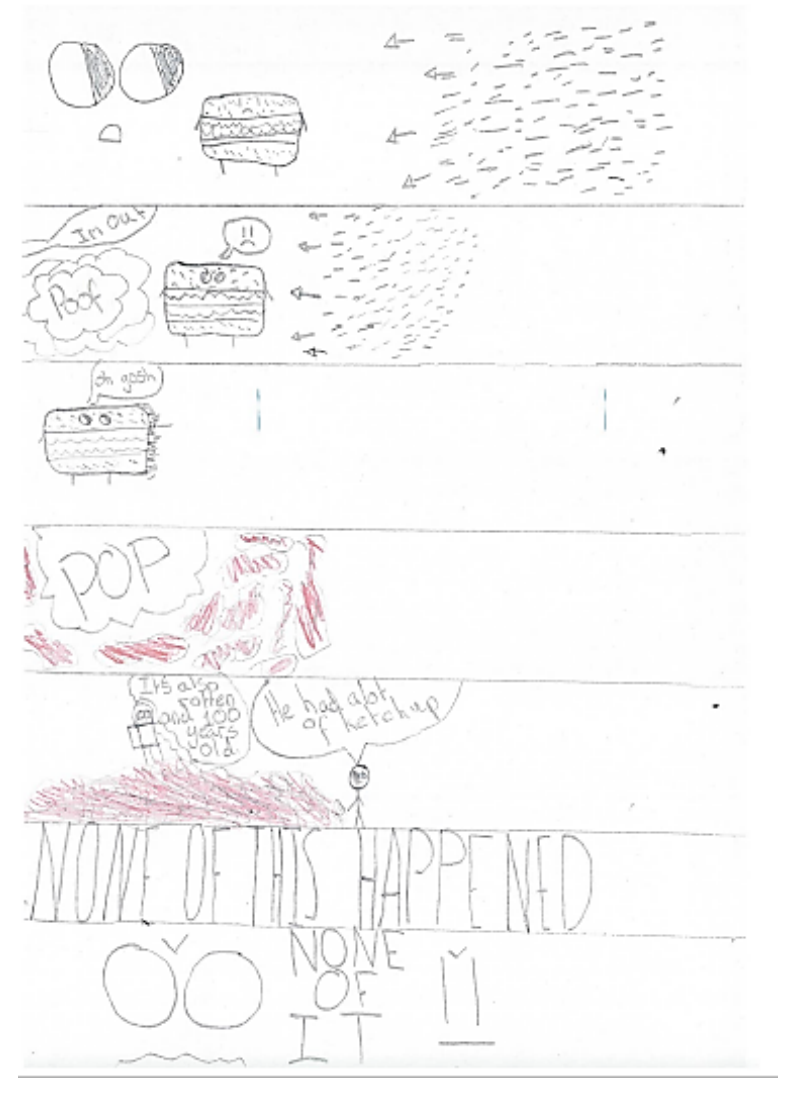

Figure 19: Page two, Jacob's comic strip.

\section{Conclusion}

Build. Building. Designing. Rebuilding. Remixing. Making. Constructing. Revisiting Chamakova's quote in the introduction, there has been a common thread to the language used to discuss how children created and published comics throughout this article. These words have been used to examine how children draw from the world around them in order to construct their own literacy worlds. 
As noted by Giovanelli (2016) when texts worlds take on physical form, as the children's comics did in their production and distribution, they become important discourse world entities in their own right. In the creation and selling of their text worlds, the Doodle Boiz and Caticorns invite an audience into their personal discourse worlds. Through the bi-directional 'feedback loop' (Canning, 2017; Stockwell, 2009) between the text and discourse world, the children have the opportunity to construct an identity linked to both their text and discourse world. Although I did not initially have high level of familiarity with the discourse world of the Doodle Boiz, the text world they built allowed me access the discourse world. In the collaboratively constructed literacy worlds the children teach us, as their audience, about their knowledge, views, experiences and identities.

Text World Theory is a valuable framework for examining how children explored their identities, play and make sense of their world in the comics they create. In the self-initiated comic strips, the children could decide for themselves what aspects of their identities, hopes, dreams and beliefs they chose to reveal with their audiences, and teach their audiences about themselves (Werth, 1999; Wilson, 2016). The comic strips reveal that the children have a complex understanding of how narrative and texts worlds work, as equal and as valid as an adults. This model of analysis demonstrates that we should not dismiss children's literacies if we are primarily excluded from the discourse world that surrounds them. Instead, we should probe, examine and, bit-by-bit construct meaning, to work out what children can teach us.

\section{Future Implications}

Comics should be used more widely in education. They have an important role in developing children's understanding of multimodality, and appear to play a crucial bridge between children's home and school literacies. Text World Theory provides a useful framework for analysis of the reading and writing process, and this is something which warrants further application, both in examining the bi-directional meaning making of children's discourse and text worlds, and as a tool for exploring how children write and play together in their literacy worlds. In addition, Text World Theory can be applied successfully to multimodal texts, offering the possibility to examine the interplay of modes in children's comics making, and positioning both the written and drawn elements of comics in equal standing.

In light of the outcomes of the project, it seems evident that it is worthwhile for schools to consider how to create opportunities for after school clubs and groups that learn and create together. Furthermore, the opportunity for children to publish and distribute comics to one 
another is crucial, allowing children to share and value their lived experiences and emerging identities as authors.

\section{Word count: 5879}

\section{References}

Bradbury, H. (2015). Introduction: How to Situate and Define action Research in Bradbury, H. (2015). The SAGE Handbook of Action Research. London: SAGE Publications.

Brophy, P. (2010). Osamu Tezuka's Gekiga: Behind the Mask of Manga in Johnson-Woods, T. (2010). Manga : An anthology of global and cultural perspectives. New York: Continuum.

Canning, P. (2017). Text World Theory and real world readers: From literature to life in a Belfast prison. Language and Literature, 26(2), 172-187.

Carr, W., \& Kemmis, S. (1988). Becoming critical : Education, knowledge and action research. London: RoutledgeFalmer.

Chamakova, S. (2015). Awkward New York: Yen Press

Cohen, L., Manion, L., \& Morrison, K. (2018). Research methods in education (Eighth ed.). Abingdon, Oxon : Routledge

Cohn, N. (2016). Interdisciplinary Approaches to Visual Narrative in Cohn, N. (2016). The visual narrative reader London ; New York, NY : Bloomsbury Academic

Comber, B. \& Mills, K. (2013). Space, Place, and Power: The Spatial Turn in Literacy Research. in Hall, K., Cremin, T., Comber, B. \& Moll, L. (2013). International handbook of research on children's literacy, learning and culture. Oxford: Wiley-Blackwell.

Cope, B. \& Kalantzis, M. (2000). Introduction in Cope, B. \& Kalantzis, M., \& New London Group, issuing body. (2000). Multiliteracies : Literacy learning and the design of social futures (Literacies). London: Routledge.

Cushing, I. (2018). 'Suddenly, I am part of the poem': Texts as worlds, reader-response and grammar in teaching poetry. English in Education, 52(1), 7-19.

Davies, P. F. (2018). The Nested Spaces of Graphic Narrative. Between, 8(15), Between, 01 July 2018, Vol.8(15).

Dowdall, C. (2006). Dissonance between the digitally created words of school and home. Literacy, 40, 153-163.

Dyson, A.H. (1993) Negotiating a Permeable Curriculum: On Literacy, Diversity, and the Interplay of Children's and Teacher's Worlds. Urbana, IL: National Council of Teachers of English.

Dyson, A.H. (1997). Writing superheroes : Contemporary childhood, popular culture, and classroom literacy.(Language and literacy series (New York, N.Y.)). New York ; London: Teachers College P.

Gavins, J. (2007). Text world theory an introduction. Edinburgh: Edinburgh University Press. Gee, J. (2010). An introduction to discourse analysis theory and method (3rd ed.). New York: Routledge.

Gee, J. (2014). Literacy and education (Routledge key ideas in education series). London: Routledge

Gee, J. (2015). The New Literary Studies in Rowsell, J., \& Pahl, K. (2015). The Routledge handbook of literacy studies (Routledge handbooks in applied linguistics). London ; New York: Routledge. 
Gee, J. (2017a). Identity and diversity in today's world, Multicultural Education Review, 9:2, 83-92

Gibbons, A. (2012). Multimodality, cognition, and experimental literature (Routledge studies in multimodality; 3). New York: Routledge.

Gibbons, A. (2016). Building Hollywood in Paddington: Text World Theory, Immersive Theatre, and Punchdrunk's The Drowned Man. In J. Gavins \& E. Lahey (Eds.). World Building: Discourse in the Mind (Advances in Stylistics) London: Bloomsbury Academic.

Giovanelli, M. (2017). Readers building fictional worlds: Visual representations, poetry and cognition. Literacy, 51(1), 26-35.

Goodman, N. (1978). Ways of worldmaking (Harvester studies in philosophy ; 5). Hassocks: Harvester Press.

Horning, A. (2011). Where to Put the Manicules: A Theory of Expert Reading. Across the Disciplines, 8(2), Across the Disciplines, 06 October 2011, Vol.8(2).

Iser, W. (1978). The act of reading: A theory of aesthetic response. London: Routledge and Kegan Paul.

Iser, W. (2006). How to do theory (How to study literature). Malden: Blackwell.

Jackson, S. (2019). Sharing Stories: A Text World Approach to Storytime in Neurohr, B., \& In Stewart-Shaw, L. (2019). Experiencing fictional worlds. Amsterdam ; Philadelphia : John Benjamins Publishing Company

Janks, H. (2010). Literacy and power (Language, culture, and teaching). New York ; London: Routledge.

Kress, G. (1997). Before writing rethinking the paths to literacy. London ; New York: Routledge.

Kress, G. (2010). Multimodality : A social semiotic approach to contemporary communication. London: Routledge.

Lahey, E. (2019). World-building as cognitive feedback loop in Neurohr, B., \& In StewartShaw, L. (2019). Experiencing fictional worlds. Amsterdam ; Philadelphia : John Benjamins Publishing Company

Lambirth, A. (2016). Exploring children's discourses of writing. English in Education, 50(3), 215-232.

Mackey, M \& Shane, M. (2013). Multimodal Literacies: Synergistic Options and Opportunities in Hall, K., Cremin, T., Comber, B. \& Moll, L. (2013). International handbook of research on children's literacy, learning and culture. Oxford: Wiley-Blackwell.

Marsh, J., \& Millard, E. (2000). Literacy and popular culture : Using children's culture in the classroom. London: Paul Chapman.

McCloud, S. (1994). Understanding comics : The invisible art. New York: HarperPerennial by arrangement with Kitchen Sink Press.

McNiff, J., \& Whitehead, J. (2010). You and your action research project (3rd ed.). London: Routledge.

Nodelman, P. (2012). Picture Book Guy Looks at Comics: Structural Differences in Two Kinds of Visual Narrative. Children's Literature Association Quarterly, 37(4), 436-444.

Oatley, K. (2003). Writingandreading: The future of cognitive poetics in Gavins, J.A. \&Gerard, S. (2003). Cognitive Poetics in Practice. London: Routledge

Ogier, S. \& Eaude, T. (2019). Introduction: Understanding the Context of Children's Lives: Supporting Holistic Education in Ogier, S. (2019) A Broad and Balanced Curriculum in Primart Schools: Educating the Whole Child London: Learning Matters 
Pahl, K. (2006). Children's popular culture in the home: Tracing cultural practices in texts. In Marsh, J., \& Millard, E. (2006). Popular literacies, childhood and schooling. London; New York: Routledge

Pahl, K., \& Rowsell, J. (2012). Literacy and education : Understanding the new literacy studies in the classroom (2nd ed.). Los Angeles; London: SAGE.

Pahl, K. \& Burnett, C. (2013). Literacy in Home and Communities in Hall, K., Cremin, T., Comber, B. \& Moll, L. (2013). International handbook of research on children's literacy, learning and culture. Oxford: Wiley-Blackwell.

Pellitteri, M. (2018). Kawaii Aesthetics from Japan to Europe: Theory of the Japanese "Cute" and Transcultural Adoption of Its Styles in Italian and French Comics Production and Commodified Culture Goods. Arts, 7(3), 2018.

Rosenblatt, L. (1938). Literature as exploration New York, London, D. Appleton-Century company, incorporated Available at: $\underline{\text { https://archive.org/details/literatureasexp/00rose } 0}$ (Accessed: 21 January 2019)

Shifman, L. (2014). Memes in digital culture. (MIT Press essential knowledge series).

Stockwell, P. (2009). Texture : A cognitive aesthetics of reading. Edinburgh: Edinburgh University Press.

Stornaiuolo, A. (2015). "Literacy as worldmaking: Cosmopolitanism, creativity, and multimodality", in Rowsell, J., \& Pahl, K. (2015). The Routledge handbook of literacy studies (Routledge handbooks in applied linguistics). London; New York: Routledge.

Tarbox, G.A \& Abate, M. (2017). Introduction in Abate, M., \& Tarbox, G.A. (2017). Graphic novels for children and young adults: A collection of critical essays Jackson: University of Mississippi Press.

Taylor, L. E. (2018). We read, we write: Investigating the relationship between children's reading and their writing in upper primary school. PhD thesis, University of Leeds. Available at: http://etheses.whiterose.ac.uk/22932/ (Accessed: 27 July 2019)

van der Bom, I., (2015). Text world theory and stories of self: a cognitive discursive approach to identity, PhD thesis, University of Sheffiled. Available at: http://etheses.whiterose.ac.uk/10110/ (Accessed: 27 July 2019)

Varela, F., Thompson, E., \& Rosch, E. (1993). The embodied mind: Cognitive science and human experience. Cambridge, Mass.: MIT Press.

Werth, P. (1995). How to Build a World (In a lot less than six days and using only what's inside your head) in Gree, K. (Ed) New Essays on Deixis: Discourse, Narrative, Literature Amsterdam: Rodopi,

Werth, P. (1999). Text worlds: Representing conceptual space in discourse. (Textual explorations). Harlow: Longman.

Wilson, B. (2016). What happened and what happened next: Kid's visual narratives across cultures in Cohn, N. (2016). The visual narrative reader London; New York, NY : Bloomsbury Academic

Wohlwend, K. ( 2008). Play as a literacy of possibilities: Expanding meanings in practices, materials, and spaces. Language Arts, 86 ( 2): 127- 136.

Wohlwend, K., Bucholz, B. and Medina, L. M. (2018). Playful Literacies and Practices of Making in Children's Imaginaries in Mills, K., Stornaiuolo, A., Smith, A., Pandya and J.Z. Mills (Eds). (2018). Handbook of writing, literacies, and education in digital cultures New York: Routledge

Wolf, S. \& Heath, S. (1992). The braid of literature: Children's worlds of reading. Cambridge, Mass.; London: Harvard University Press. 
